\title{
Research on R\&D Investment, Corporate Leverage and Firm Performance: Based on Chinese Manufacturing Industry
}

\author{
Yuan $\mathrm{Gao}^{1 . *}$ \\ ${ }^{1}$ Beijing jiaotong University, China
}

\begin{abstract}
With the development of science and technology, Chinese manufacturing industry is facing transformation and upgrading, and innovation is an important driving force to promote industrial transformation and upgrading. Therefore, based on the background of Chinese manufacturing transformation and upgrading, this paper uses fixed effect model to study the relationship between R \& D investment and corporate performance, and the moderating effect of corporate leverage. The study finds that the greater the $\mathrm{R} \& \mathrm{D}$ investment of enterprises is, the better the performance of enterprises is. Meanwhile, the leverage of enterprises has a negative moderating effect on the relationship between R \& D investment and enterprise performance. Therefore, enterprises should pay attention to their own $\mathrm{R} \& \mathrm{D}$, reduce their debt levels, and promote the transformation and upgrading of enterprises. At the same time, the government should introduce corresponding preferential policies to encourage enterprises to carry out R \& D and deleverage, in order to promote the healthy development of industrial economy.
\end{abstract}

\section{Introduction}

Manufacturing is an important part of national development. Since the 19th National Congress, General Secretary $\mathrm{Xi}$ Jinping has repeatedly made important instructions on ' vigorously developing manufacturing and accelerating the transformation and upgrading of China 's manufacturing industry from low-end to high-end. ' The transformation and upgrading of the manufacturing industry are inseparable from the innovation of technology. However, there are different opinions on whether R \& D investment can effectively improve enterprise performance. Zhang and Zhang (2014) ${ }^{1}$ proposed that R \& $\mathrm{D}$ activities of enterprises are significantly negatively correlated with the performance of enterprises in the year of R \& D and the following two years, while Hsieh et al. $(2003)^{2}$ proposed that R \& D investment can significantly increase market value, about twice that of fixed asset investment. Therefore, it is necessary to study the impact of manufacturing $\mathrm{R} \& \mathrm{D}$ investment on enterprise performance.

According to statistics, there are only $25,500 \mathrm{R} \& \mathrm{D}$ institutions in industrial enterprises above designated size, accounting for only $7.8 \%$ of all enterprises above designated size. Therefore, increasing the R \& D level of manufacturing enterprises is the top priority. However, $\mathrm{R}$ $\&$ D of enterprises has the characteristics of high risk, long period and information asymmetry, and it needs sufficient and stable financial support. China's economy is in transition, debt financing is the main way of corporate financing. The high leverage of enterprises has affected the healthy development of China's economy, and even brought financial crisis to enterprises.

Based on the above, referring to previous studies, the paper takes the sample of manufacturing listed companies from 2010 to 2020 to study the impact of R \& D investment on enterprise performance, and whether the leverage of enterprises has an impact on the relationship between R \& D investment and enterprise performance. Our innovation lies mainly in: on the one hand, R \& D investment is affected by the capital structure of the enterprise itself, so we introduce the variable of enterprise leverage to study its role in $\mathrm{R} \& \mathrm{D}$ investment and enterprise performance. On the other hand, since China is in an important stage of manufacturing transformation and upgrading, we study the impact of R \& D investment of manufacturing enterprises on enterprise performance, which has important practical significance for the development of industrial economy.

\section{Theoretical analysis and assumptions}

\subsection{Effect of enterprise $R$ \& $D$ investment on enterprise performance}

$\mathrm{R} \& \mathrm{D}$, as the main driving force of innovation, has been a hot topic of research. With the deepening of research, domestic and foreign scholars focus on the impact of R\&D investment in different industries. Wang $(2021)^{3}$ found that innovation investment of retail enterprises is conducive to enhancing business performance. Guo and Sun $(2020)^{4}$ found that R \& D investment has a significant positive impact on market performance of high-tech

\footnotetext{
*Corresponding author: 20120654@bjtu.edu.cn
} 
enterprises. The reason is that the R \& D achievements obtained by increasing $\mathrm{R} \& \mathrm{D}$ investment can increase the added value of products, enable enterprises to obtain unique market competitiveness, more market share and higher visibility, to improve enterprise performance and promote the development of enterprises. So, we assume that $\mathrm{H} 1$ :

H1: Increasing R\&D investment can significantly improve enterprise performance.

\subsection{Moderating effect of corporate leverage}

Debt financing is an important way of enterprise financing. Compared with equity financing, debt financing has the advantages of low financing cost and low risk. Therefore, debt financing is a way of choice for more enterprises. However, the interest generated by excessive debt is easy to make enterprises fall into financial crisis. $\mathrm{R} \& \mathrm{D}$ is a process of high investment, high risk and long cycle. High leverage enterprises face the financial risk of huge interest. Facing high-risk investment of R \& D, enterprises will not try easily. Therefore, high leverage increases enterprise financial cost, inhibits R \& D investment, and reduces enterprise performance (Liu et al., 2019) ${ }^{5}$. Therefore, we assume that $\mathrm{H} 2$ :

$\mathrm{H} 2$ : Leverage negatively moderates the relationship between R \& D investment and firm performance.

\section{Research design}

\subsection{Sample selection and Variable definition}

We select the manufacturing companies listed in 20102020, excluding more missing value data samples and ST samples, and shrink the tail to avoid the impact of extreme values. The data used in the sample are from CSMAR database, we use Stata 15 for statistical analysis.

(1) Explanatory variables: Referring to existing research, we use R \& D investment amount/current year ' $\mathrm{S}$ operating income to represent the intensity of $\mathrm{R} \& \mathrm{D}$ investment. (2) Explained variables: corporate performance is taken as the explained variable. We use Tobin's Q value to measure corporate performance. Tobin' s Q value measures the ability of enterprises to use their own assets to create profits. The higher the value of this index, the greater the value created by the enterprise. (3) Adjustment variables: the corporate leverage is used as a moderator variable. Referring to the existing research, the ratio of total liabilities to total assets is used to measure the corporate leverage. Variables are defined as follows:

Table1. Variable definition

\begin{tabular}{|c|c|c|}
\hline Type & Variable name & Variable meaning \\
\hline variable & $\begin{array}{c}\text { R\&D } \\
\text { investment } \\
\text { intensity (RD) }\end{array}$ & $\begin{array}{c}\text { R\&D investment } \\
\text { amount/operating } \\
\text { income }\end{array}$ \\
\hline $\begin{array}{c}\text { Interpreted } \\
\text { variable }\end{array}$ & $\begin{array}{c}\text { Tobin Q value } \\
\text { (Performance) }\end{array}$ & $\begin{array}{c}\text { Market value of } \\
\text { enterprise/placement } \\
\text { cost of enterprise } \\
\text { assets }\end{array}$ \\
\hline $\begin{array}{c}\text { Regulated } \\
\text { variable }\end{array}$ & $\begin{array}{c}\text { Enterprise } \\
\text { Leverage (Lev) }\end{array}$ & Total liabilities/assets \\
\hline
\end{tabular}

\begin{tabular}{|c|c|c|}
\hline \multirow{7}{*}{$\begin{array}{l}\text { Control } \\
\text { variable }\end{array}$} & $\begin{array}{l}\text { Company Size } \\
\text { (Size) }\end{array}$ & $\begin{array}{l}\text { Ln (year-end total } \\
\text { assets) }\end{array}$ \\
\hline & $\begin{array}{l}\text { Risk level } \\
\text { (Risk) }\end{array}$ & $\begin{array}{l}\text { (Net profit }+ \text { income } \\
\text { tax expense }+ \text { financial } \\
\text { expense)/ (net profit } \\
+ \text { income tax expense) }\end{array}$ \\
\hline & $\begin{array}{l}\text { Operating Cash } \\
\text { flow (Cash) }\end{array}$ & $\begin{array}{c}\text { Ln }(\mid \text { net cash flow } \\
\text { from operating } \\
\text { activities } \mid)\end{array}$ \\
\hline & $\begin{array}{l}\text { Growth ability } \\
\text { (Growth) }\end{array}$ & $\begin{array}{c}\text { (Total assets of this } \\
\text { year-total assets of } \\
\text { last year)/total assets } \\
\text { of this year }\end{array}$ \\
\hline & $\begin{array}{c}\text { Major } \\
\text { shareholder } \\
\text { control degree } \\
\text { (FIR) }\end{array}$ & $\begin{array}{l}\text { Number of shares } \\
\text { held by the largest } \\
\text { shareholder/total } \\
\text { share capital of the } \\
\text { enterprise }\end{array}$ \\
\hline & $\begin{array}{l}\text { Years on the } \\
\text { market (Age) }\end{array}$ & $\begin{array}{c}\text { Years of } \\
\text { establishment of } \\
\text { enterprises }\end{array}$ \\
\hline & $\begin{array}{c}\text { Operational } \\
\text { capability (TAT) }\end{array}$ & $\begin{array}{c}\text { Net operating } \\
\text { income/average total } \\
\text { assets }\end{array}$ \\
\hline
\end{tabular}

\subsection{Model setting}

(1) In order to study the impact of R \& D investment on enterprise performance, and sets the model as follows:

$$
\text { Performance }_{i t}=a+\beta \times R D_{i t}+\lambda \times \text { Controls }_{i t}+\varepsilon_{i t}
$$

(2) In order to study the moderating effect of corporate leverage, the following model is established:

$$
\begin{aligned}
\text { Performance }_{i t}= & a+\beta_{1} \times R D_{i t}+\beta_{2} \times \text { Lev }_{i t}+\beta_{3} \times R D_{i t} \times \text { Lev }_{i t} \\
& +\lambda \times \text { Controls }_{i t}+\varepsilon_{i t}
\end{aligned}
$$

\section{Empirical results}

\subsection{Descriptive statistics}

Table2. Descriptive statistics

\begin{tabular}{|c|c|c|c|c|c|}
\hline Variable & $\mathrm{N}$ & Mean & Std. & Min & Max \\
\hline Performance & 1,820 & 2.03 & 1.40 & 0.15 & 17.73 \\
\hline RD & 1,820 & 3.63 & 3.18 & 0.04 & 19.88 \\
\hline Risk & 1,820 & 2.54 & 3.37 & 0.48 & 12.07 \\
\hline TAT & 1,820 & 0.74 & 0.44 & 0.11 & 2.51 \\
\hline FIR & 1,820 & 32.01 & 14.15 & 8.12 & 75.05 \\
\hline Size & 1,820 & 22.66 & 1.27 & 19.96 & 25.84 \\
\hline Cash & 1,820 & 19.58 & 1.75 & 12.01 & 24.39 \\
\hline Growth & 1,820 & 0.13 & 0.49 & -0.83 & 10.89 \\
\hline Age & 1,820 & 21.62 & 3.43 & 15.00 & 28.00 \\
\hline Lev & 1,820 & 0.46 & 0.19 & 0.07 & 0.95 \\
\hline
\end{tabular}

It can be seen from Table 2 that the performance gap between manufacturing enterprises is large, with the maximum value of 17.73 and the minimum value of 0.15 . 
At the same time, the average performance of China' $\mathrm{s}$ manufacturing enterprises is 2.03, indicating that China's performance level is generally low. The minimum intensity of R \& D investment is 0.48 , and the maximum intensity is 12.07 , which shows that there is a big gap between China' $s$ enterprises' attention to $R$ \& $D$. In addition, an average of 3.63 , indicating that China's enterprises' attention to R \& D needs to be strengthened.

\subsection{Hypothesis test results}

Model 1 is used for regression to verify Hypothesis H1. Table 3 shows the results of hypothesis $\mathrm{H} 1$ and H2. Since the fixed effect model can make the results more accurate, we use the fixed effect model for regression, and the result is shown in Column (1).

Table3. Regression results of R \& D investment on corporate performance and leverage regulating effect

\begin{tabular}{|c|c|c|c|}
\hline VARIABLES & $\begin{array}{c}(1) \\
\text { Performance } \\
\end{array}$ & $\begin{array}{c}(2) \\
\text { Performance } \\
\end{array}$ & $\begin{array}{c}(3) \\
\text { Performance }\end{array}$ \\
\hline $\mathrm{RD}$ & $\begin{array}{c}0.0337^{* * *} \\
(0.00920)\end{array}$ & $\begin{array}{c}0.0286^{* * *} \\
(0.00914)\end{array}$ & $\begin{array}{c}0.0907 * * * \\
(0.0227)\end{array}$ \\
\hline Lev & & $\begin{array}{c}-1.047 * * * \\
(0.166)\end{array}$ & $\begin{array}{c}-0.626 * * * \\
(0.217)\end{array}$ \\
\hline Lev* RD & & & $\begin{array}{c}-0.149^{* * *} \\
(0.0499)\end{array}$ \\
\hline Risk & $\begin{array}{c}-0.0143^{*} \\
(0.00837)\end{array}$ & $\begin{array}{c}0.00415 \\
(0.00878)\end{array}$ & $\begin{array}{c}0.00362 \\
(0.00876)\end{array}$ \\
\hline TAT & $\begin{array}{c}0.0789 \\
(0.0687)\end{array}$ & $\begin{array}{c}0.127^{*} \\
(0.0684)\end{array}$ & $\begin{array}{l}0.137 * * \\
(0.0683)\end{array}$ \\
\hline FIR & $\begin{array}{c}-0.00355^{*} \\
(0.00206)\end{array}$ & $\begin{array}{c}-0.00365^{*} \\
(0.00204)\end{array}$ & $\begin{array}{l}-0.00369^{*} \\
(0.00204)\end{array}$ \\
\hline Size & $\begin{array}{c}-0.668 * * * \\
(0.0348)\end{array}$ & $\begin{array}{c}-0.583^{* * * *} \\
(0.0369)\end{array}$ & $\begin{array}{c}-0.576 * * * \\
(0.0369)\end{array}$ \\
\hline Cash & $\begin{array}{c}0.155^{* * *} \\
(0.0247)\end{array}$ & $\begin{array}{c}0.134 * * * \\
(0.0247)\end{array}$ & $\begin{array}{c}0.133 * * * \\
(0.0246)\end{array}$ \\
\hline Growth & $\begin{array}{c}-0.0180 \\
(0.0573)\end{array}$ & $\begin{array}{l}-0.0342 \\
(0.0567)\end{array}$ & $\begin{array}{c}-0.0439 \\
(0.0567)\end{array}$ \\
\hline Age & $\begin{array}{c}0.00240 \\
(0.00841)\end{array}$ & $\begin{array}{c}0.00218 \\
(0.00832)\end{array}$ & $\begin{array}{c}0.00435 \\
(0.00833)\end{array}$ \\
\hline Constant & $\begin{array}{c}14.05 * * * \\
(0.552)\end{array}$ & $\begin{array}{c}12.96^{* * * *} \\
(0.573)\end{array}$ & $\begin{array}{c}12.59^{* * *} \\
(0.585)\end{array}$ \\
\hline $\mathrm{N}$ & 1,820 & 1,820 & 1,820 \\
\hline $\mathrm{R}^{2}$ & 0.258 & 0.274 & 0.278 \\
\hline
\end{tabular}

From the regression results, $\mathrm{R} \& \mathrm{D}$ investment and corporate performance are significantly positively correlated at the level of $1 \%$, indicating that the greater the R \& D investment of manufacturing enterprises is, the higher the level of corporate performance is, and Hypothesis H1 is proved. This is because Enterprises increase R \& D investment for product and technology updates. On the one hand, it will enable enterprises to seize a larger market share and improve competitiveness. On the other hand, technology updates will also reduce the production cost of enterprises, and the two jointly promote the improvement of enterprise performance.

Next, we use Model 2 to verify the hypothesis H2. The regression results are shown in (2) and (3). It can be seen from the regression results that the leverage of enterprises is negatively correlated with corporate performance. From the interaction item of column (3), the coefficient of interaction item is negatively correlated with enterprise performance at the level of $1 \%$, indicating that the leverage of enterprises has a negative moderating effect on the relationship between R \& D investment and enterprise performance, so $\mathrm{H} 2$ is proved. This may be because the higher the leverage of enterprises is, the greater the operational risk and financial crisis they face, and the R \& $\mathrm{D}$ process is a high-risk and long-term process. Therefore, in order to avoid risks, highly leveraged enterprises tend to reduce $\mathrm{R} \& \mathrm{D}$ investment, thereby reducing corporate performance to a certain extent.

\section{Conclusion}

We take China's manufacturing listed companies from 2010 to 2020 as the research object, and study the relationship between $\mathrm{R} \& \mathrm{D}$ investment and corporate performance, as well as the moderating effect of corporate leverage. The study finds that $\mathrm{R} \& \mathrm{D}$ investment of manufacturing enterprises is positively correlated with corporate performance. The more enterprises pay attention to $\mathrm{R} \& \mathrm{D}$ investment, the better corporate performance is. In addition, corporate leverage is negatively correlated with corporate performance. The higher the corporate leverage is, the worse the corporate performance is. At the same time, higher leverage has a negative moderating effect on the relationship between R \& D investment and corporate performance.

Therefore, we make the following suggestions. Firstly, manufacturing enterprises should pay attention to their own R \& D investment, and introduce advanced technology and talents to enhance their own R \& D level. Secondly, enterprises should optimize capital structure, reduce debt level, and improve their own financial and cost management system, in order to promote high-quality development of enterprises. Finally, the government should introduce appropriate preferential policies to encourage enterprises to research and development, deleveraging, in order to promote the healthy development of industrial economy.

\section{References}

1. Zhang J, Zhang LH. The impact of R \& D investment on corporate performance - Empirical evidence from 2009-2011 Chinese listed companies [J].Scientific Decision-making, 01(2014).

2. Hsieh P. H., Mishra C. S., Gobeli D. H. The return on $\mathrm{R} \& \mathrm{D}$ versus capital investment in pharmaceutical and chemical industries $[\mathrm{J}]$. IEEE Transactions on Engineering Management, 02(2003).

3. Wang JY. Executive characteristics, innovation investment and business performance - Based on empirical evidence of listed retail enterprises in China [J]. Business Economic Research, 06(2021).

4. Guo XQ, Sun YM. R \& D investment, technology accumulation and market performance of high-tech enterprises [J]. Scientific Research, 09(2020).

5. Liu XG, Liu YC. Leverage rate, long-term use of short debt and enterprise performance $[\mathrm{J}]$. Economic Research,07(2019). 